\title{
Genetic polymorphism in psoriasis and its meaning for the treatment efficacy in the future
}

\author{
Agnieszka Osmola-Mańkowska ${ }^{1}$, Ewa Teresiak-Mikołajczak ${ }^{1}$, Marzena Skrzypczak-Zielińska², Zygmunt Adamski ${ }^{1}$
}

'Department of Dermatology, Psoriasis and Novel Therapies in the Dermatology Unit, Poznan University of Medical Sciences, Poznan, Poland

2Institute of Human Genetics, Polish Academy of Sciences, Poznan, Poland

Adv Dermatol Allergol 2018; XXXV (4): 331-337

DOI: https://doi.org/10.5114/ada.2018.77661

\begin{abstract}
The concept of personalized medicine is a new individualized approach which helps application of the targeted therapy. In fact, tailored medicine is mostly present in the field of life-threatening diseases such as oncology. However, skin diseases as such might be regarded as a potential area of implementation of this approach in the future. Stratified medicine in polygenetic and heterogeneous diseases, such as psoriasis, is more complex. Rapid development of science and novel molecular techniques led to better understanding of molecular pathogenetic pathways of many diseases including psoriasis. Identification of the particular immunopathogenetic pathways led to further development of targeted therapies such as biologic drugs. Actually the goal of individualized therapy is to determine the identical homogenous subgroups of patients, according to a biomarker, in which the response to that therapy will be the best and will carry the lowest risk of side effects. This review attempts to analyze the associations between polymorphisms of certain genes and the increased risk of developing psoriasis or psoriatic arthritis. The review of literature has also included the studies investigating the associations between gene polymorphisms and response to biologic therapy in psoriasis and psoriatic arthritis patients.
\end{abstract}

Key words: psoriasis, psoriatic arthritis, personalized medicine, therapy, biologics.

\section{The concept of personalized medicine}

The concept of personalized medicine is a new individualized approach which helps application of the targeted therapy: "the right patient with the right drug at the right dose at the right time". In practice, tailored medicine is mostly present in the field of life-threatening diseases such as clinical oncology, hematology or neurologic disorders.

Actually elements of stratified medicine are also utilized in the management of skin melanoma, non-melanoma skin cancers as well as skin lymphomas. Other skin diseases might also be regarded as a potential area of implementation of this approach in the future. However, stratified medicine in polygenetic and heterogeneous diseases, such as psoriasis, is more complex.

Rapid development of science and novel molecular techniques led to better understanding of molecular pathogenetic pathways of many diseases including psoriasis. In the last two decades, great progress has been made in understanding of the genetic background of psoriasis. Identification of the particular immunopathogenetic pathways led to further development of targeted therapies such as monoclonal antibodies and fusion proteins - the so-called biologicals. This novel group of drugs at the beginning had revolutionized treatment of rheumatic diseases e.g. rheumatoid arthritis (RA), then gastroenterological disorders such as Crohn's disease (CD) or ulcerative colitis and finally skin diseases with psoriasis (Ps) and psoriatic arthritis (PsA). In many cases, when standard drugs were not effective, they allow to obtain remission of the disease during the treatment. In fact, complex pathophysiological mechanisms result in clinical heterogeneity of the disease course. Although at this moment, the range of available antipsoriatic biological drugs is quite wide, we are not able to predict which drug will bring the best results in any particular patient. Moreover, this form of therapy is still very expensive and associated with some relevant side effects.

Address for correspondence: Agnieszka Osmola-Mańkowska, Department of Dermatology, Psoriasis and Novel Therapies in the Dermatology Unit, Poznan University of Medical Sciences, 49 Przybyszewskiego St, 60-355 Poznan, Poland, phone: +48 618691278 , e-mail: agnieszka.osmola@wp.pl Received: 23.01.2017, accepted: 16.03.2017. 
Actually, the goal of individualized therapy is to determine the identical homogenous subgroups of patients, according to a biomarker, in which the response to that therapy will be the best and will carry the lowest risk of side effects. Implementation of personalized medicine in clinical practice is possible due to biomarkers that are evaluated objectively on the basis of genetic and epigenetic testing together with more conventional analysis (e.g. blood, urine tests). Biomarkers serve as indicators of normal biological and pathogenic processes or pharmacological responses to therapy. Biomarkers are classified as diagnostic biomarkers (early diagnostic of PsA in psoriatic patients) indicating the onset of the disease; prognostic biomarkers (able to predict which patients will develop cardiovascular disorders e.g. the length of tellers or micro-RNAs) and predictive biomarkers (able to predict the response to particular treatment e.g. single nucleotide polymorphisms - SNPS). Detection of biomarkers characteristic of Ps and PsA would be very helpful in choosing the optimal therapeutic approach and predicting the response to a particular treatment (to maximize efficacy and minimize side effects) as well as achieving long-term remissions. The application of biomarkers in clinical practice would increase patient satisfaction and reduce the treatment costs. According to an alternative classification, biomarkers can be distinguished in categories: type 0 - correlating with the severity of the disease (e.g. HLA-CW*0602 associated with an early onset, more severe course of Ps, but not PsA), type 1 - useful for monitoring the efficacy of therapy in relation to the mechanism of action (e.g. IL-23/IL-17 axis) and the most important type 2 - predicting the treatment efficacy (e.g. SNP in TNFAIP3 gene and response to anti-TNF therapy or better and quicker response to ustekinumab in HLA-CW*0602).

Unfortunately, since that time not even one highly specific biomarker has been determined in psoriasis. Such an approach may not only result in cost savings, but also generate some ethical dilemmas [1].

\section{Genetic benefits in dermatology}

Intensive development of pharmacogenetics and personalized medicine depends largely on the progress in molecular biology. Especially results from the Human Genome Project in 2003, finding that only near 25000 human genes exist and characterization of over 3.1 million human SNPS opened a new door to genetic functional studies, improving the disease diagnosis and giving the possibility to explain the background of inter-individual variability in response to treatment [2, 3].

The size of the human genome, meaning the total number of nucleotides in one representative copy of nuclear DNA, is approximately 3 billion bases. Currently, it is possible to read the DNA sequence of the whole genome in 2 days with the already decreased cost of $\$ 1000$. These opportunities result from the launch in 2005 of high throughput technology, the next generation sequencing (NGS) [4]. The wide analyses of the whole genome (WGA) are so far spread mostly as a scientific tool, but the technology has already started to be used in routine diagnostics. Especially, an economical and useful approach is sequencing a part of a genome, for example the proteincoding regions - whole exome sequencing (WES), which represents only $1.5 \%$ of the total genome, but contains approx. $85 \%$ of the total DNA changes predisposing to genetic diseases [5]. It is important to note that the NGS allows deep, i.e. multiple, reading of each base that is useful for the analysis of genetic heterogeneous materials and somatic mutation detection in tumor, such as melanoma [6]. The list of rare heredity skin diseases is long. However, in most cases, where genetic factors are well described and characterized, e.g. neurofibromatosis or stiff skin syndrome, in practice for mutation detection, the Sanger sequencing is used as a gold standard. This method is dedicated to analysis of only one specified gene or its region. The final price of DNA Sanger sequencing per sample is about \$5-6.

In diseases like psoriasis, where the genetic component of disease is not exactly defined and often shared with different factors e.g. environmental condition, the scientific research using DNA microarrays analysis is carried out. The basis of microarray chips is complementarity of nucleic acid bases and the hybridization process. It allows research on the whole genome level, where hundreds of thousands of SNPS as a target can be analyzed in patient and control groups at the same time and their association with a particular feature can be determined. This analysis is called a genome-wide association study (GWAS) and supports discovering of new genetic correlations as well as study directions. Moreover, microarrays are widely applied in high throughput gene expression analyses. If a gene is expressed in the sample, its messenger RNA (mRNA) will hybridize to complementary DNA probe on the chip. This method enables a simultaneous and parallel indication of the expression level of thousands of genes and is a powerful laboratory tool [7]. The cost of reagents for expression estimation for one sample is \$750-800. An older technique, real time PCR, is much cheaper per test, but provides information of only single genes and more genetic material is required.

Looking to the future, the enormous automation in molecular biology and whole genome analyses shows possibilities for the development of new research fields in skin diseases diagnosis and treatment with a focus on the individual patient. Perhaps it is no exaggeration to conclude that the genetics can revolutionize the dermatology.

\section{Personalized therapy in psoriasis}

Pathogenesis of Ps involves interaction of genetic, immunological and environmental factors. The complex 
etiopathogenesis of the disease is manifested by different clinical variants, a variable and unpredictable course and variable rate of associated diseases such as psoriatic arthritis, cardiovascular disorders (CVD) or metabolic diseases.

There are many treatment options available in PS from topical to systemic therapies and from standard to innovative targeted therapies. Unfortunately, the successful control of the disease is very difficult because of its clinical heterogeneity, availability of many treatment methods as well as distinct response to treatment, adverse reactions and drug toxicity. Thus, it is of great importance to identify the Ps biomarkers that may allow to predict therapy response or disease prognosis (theranostic biomarkers) and implement a stratified medicine approach in the disease management. Personalized management of Ps patients should involve a multidisciplinary and integrated clinical approach.

To make the most optimal treatment decision, the dermatologist must have a detailed overview of the patient's history and lifestyle relevant information such as demographics, personal and family history as well as drug history, the vaccination status or cardiovascular profile [1].

Genetic background of Ps has been confirmed by population and family studies as well as higher concordance rates in monozygotic twins [8, 9]. Genetic studies of Ps background have also led to the identification of the mutation in the IL-36RN gene encoding the anti-inflammatory IL-36 receptor antagonist (IL-36Ra) and have supported the hypothesis that generalized pustular psoriasis (GPP) is a disease of distinct etiology [10]. More advanced GWAS revealed 36 independent psoriasis-associated genetic regions in the European population and 5 more in the Chinese population [11]. Psoriasis susceptibility genes include mainly skin-specific genes and immune-related genes of the innate and adaptive immunity. Psoriasis susceptibility region 1 (PSORS1 known also as HLA-C) within the major histocompatibility complex (MHC) is considered to be the strongest susceptibility locus [12]. In turn, the HLA-CW*0602 allele of the HLA-C gene is associated with an early onset, before the age of 40 , and positive family history of Ps [13]. Genome-wide association studies have also identified several psoriasis-related chromosomal regions such as the receptors for interleukin 23 (IL-23) and IL-12B [14, 15]. The results of the Indhumathi study suggest that the variants of IL-12B (rs3212227) and IL-23R (rs2201841) genes are related to an increased risk of developing Ps in the ethnic South Indian Tamils population [16]. A meta-analysis of 997 Ps cases and 943 control subjects for $-238 \mathrm{G}>\mathrm{A}$ and of 1,156 psoriasis cases and 1,083 control subjects for $-308 \mathrm{G}>\mathrm{A}$ polymorphism of the TNF gene showed that a significantly increased risk was associated with the variant $-238 \mathrm{G}>\mathrm{A}$ and GA + AA genotypes, compared with the GG genotype, whereas the GA + AA genotypes in position -308G >A were correlated with a reduced psoriasis risk. These findings suggest that
$-308 \mathrm{G}>\mathrm{A}$ and $-238 \mathrm{G}>\mathrm{A}$ polymorphisms of the TNF gene might serve as diagnostic biomarkers of psoriasis [17].

The recent genetic data support the important role of the gene's variants engaged in different immunological processes and pathways in psoriasis such as: antigen presentation (HLA-C, ERAP1, ERAP2, MICA), T-cell polarization (RUNX1, RUNX3, STAT3, TAGAP, IL-4, IL-13), IL-23/IL-17 axis (IL12BP40, IL23AP19, IL23R, JAK2, TYK2), negative regulators of immune response (TNFAIP3, TNIP1, NFKBIA, CARD14, IL36RN, SOCS1, ZC3H12C), innate immunity (TRAF3IP2, CARD14, C-REL, DDX58, IFIH1) and type 1 INF (IL28RA, RNF114) [1].

Psoriasis may be accompanied in 10-30\% of cases by PsA [18]. Moreover, pathophysiological mechanisms of other inflammatory conditions such as RA or CD are at some point similar to Ps and can be treated with the same biological agents that selectively block TNF- $\alpha$ (etanercept, infliximab, adalimumab).

Biologicals, especially anti-TNF drugs have been shown to be one of the most effective forms of therapy in Ps as well as in PsA, RA and CD. However, they are not effective in all patients and response to the drug may diminish during the treatment time and lead to stopping or switching the therapy. The most common reason for discontinuing biological treatment is lack of effectiveness [19]. Moreover, some patients develop severe adverse drug reactions. Therefore, it is necessary to implement the solutions of personalized therapy in order to discover new therapeutic targets that allow the development of more effective drugs and optimize the treatment, reduce the risk of side effects and costs of the therapy [20-22].

Characterization of the pharmacogenetic profile and individual genetic variation associated with susceptibility to certain diseases and response to specific treatment, constitutes the foundation of personalized medicine. Recent studies identified genetic predictors for the clinical response to biologics. Some polymorphisms in genes encoding tumor necrosis factor (TNF), TNF receptor superfamily $1 \mathrm{~B}$ (TNFR1B) and TNF induced protein 3 (TNFAIP3) have been associated with response to antiTNF therapy in patients with Ps [23]. Several studies have also associated polymorphisms at genes encoding cytokines involved in the pathogenesis of Ps with response to treatment $(I L-12 B, I L-1, I L-10, I L-13, I L-17, I L-21, I L-23)$. Batalla et al. established that SNP rs4819554 in the promoter region of IL-17RA gene significantly influences the response to anti-TNF drugs at 12-week therapy among Ps patients [24].

Recent studies confirmed associations between genetic markers and response to drug treatment in RA, PSA and Ps. A multicenter study on the Greek population of patients suffering from Ps demonstrated the associations of TNF (rs1799124) and TNF receptor II (TNFRSF1B) genes polymorphisms (rs1061622) and positive response to treatment with etanercept. None of the studied poly- 
Table 1. Associations of gene polymorphisms with susceptibility to Ps, PsA and RA as well as response to treatment

\begin{tabular}{|c|c|c|c|c|}
\hline Gene & Gene function & Genetic variant & Associations & References \\
\hline TNFR1B & $\begin{array}{l}\text { TNF receptor superfamily } 1 B \text {; binds tumor } \\
\text { necrosis factor involved in apoptosis and } \\
\text { inflammation, proliferation, survival, and } \\
\text { differentiation }\end{array}$ & rs1061622 & $\begin{array}{l}\text { Positive response to etanercept, } \\
\text { poor response to infliximab and } \\
\text { adalimumab in Ps }\end{array}$ & Vasilopoulos 2012 [25] \\
\hline \multirow[t]{2}{*}{ TNFAIP3 } & \multirow{2}{*}{$\begin{array}{l}\text { TNF- } \alpha \text { induced protein } 3 \text { gene; expression } \\
\text { rapidly induced by TNF, inhibits NF-KB } \\
\text { activation, } \\
\text { TNF-mediated apoptosis, critical for limiting } \\
\text { inflammation by terminating TNF-induced } \\
\text { NF-KB responses }\end{array}$} & rs2230926 & Positive response to anti-TNF in Ps & Tejasvi 2012 [26] \\
\hline & & rs610604 & $\begin{array}{l}\text { No association with response } \\
\text { to ustekinumab in Ps }\end{array}$ & Talamonti 2013 [30] \\
\hline \multirow[t]{3}{*}{ IL-12B } & \multirow[t]{3}{*}{$\begin{array}{l}\text { Ligand IL23R } \\
\text { Differentiation of Th1 cells; stimulation of } \\
\text { INF- } \gamma \text { and TNF- } \alpha \text { production; expansion and } \\
\text { maintenance of Th17 cells }\end{array}$} & rs3212227 & Ps & $\begin{array}{c}\text { Cargil 2007 [15], Capon } \\
2007 \text { [14], Indhumanthi } \\
2016 \text { [16], Nair } 2008 \\
\text { [31] }\end{array}$ \\
\hline & & & $\begin{array}{l}\text { Early onset of Ps } \\
\text { PsA } \\
\text { PsA, Ps }\end{array}$ & $\begin{array}{l}\text { Smith } 2008 \text { [32] } \\
\text { Filer } 2008 \text { [33] } \\
\text { Liu } 2008 \text { [34], } \\
\text { Li } 2009 \text { [35] }\end{array}$ \\
\hline & & rs6887695 & $\begin{array}{l}\text { PsA } \\
\text { PsA, Ps }\end{array}$ & $\begin{array}{l}\text { Cargil } 2007 \text { [15], Capon } \\
2007 \text { [14], Smith 2008 } \\
\text { [32], Nair } 2008 \text { [31], } \\
\text { Filer } 2008 \text { [33], } \\
\text { Liu } 2008 \text { [34] } \\
\text { Li } 2009 \text { [35] }\end{array}$ \\
\hline \multirow[t]{3}{*}{ IL-13 } & \multirow[t]{3}{*}{$\begin{array}{l}\text { Genetic variations may result in } \\
\text { deregulation of the Th1 and Th17 pathways, } \\
\text { involved in B-cell differentiation }\end{array}$} & rs20541 & $\begin{array}{c}\text { Ps } \\
\text { PsA } \\
\uparrow \text { PsA in Ps } \\
\text { PsA }\end{array}$ & $\begin{array}{l}\text { Chang } 2008[36] \\
\text { Duffin } 2009[37] ; \\
\text { Eder } 2011[38] \\
\text { Bowes } 2011[39]\end{array}$ \\
\hline & & rs848 & $\begin{array}{l}\text { PsA } \\
\uparrow \text { PsA in Ps } \\
\text { PsA }\end{array}$ & $\begin{array}{l}\text { Duffin } 2009[37] \\
\text { Eder } 2011[38] \\
\text { Bowes } 2011[39]\end{array}$ \\
\hline & & rs1800925 & $\begin{array}{l}\text { Ps, RA } \\
\uparrow \text { PsA in Ps } \\
\quad \text { PsA }\end{array}$ & $\begin{array}{c}\text { Li } 2009[35] \\
\text { Eder } 2011[38] \\
\text { Bowes } 2011[39]\end{array}$ \\
\hline \multirow[t]{3}{*}{ IL-23R } & \multirow{3}{*}{$\begin{array}{l}\text { Receptor of IL-23, hyperproliferation of } \\
\text { psoriatic skin, expansion and maintenance } \\
\text { of Th17 cells, promoter of chronic } \\
\text { inflammation in RA, IL-23 inhibits the } \\
\text { development of Treg cells, necessary for } \\
\text { differentiation of Th17 }\end{array}$} & rs7530511 & $\begin{array}{c}\text { Early onset of Ps } \\
\text { Ps } \\
\text { PsA } \\
\text { RA, PsA }\end{array}$ & $\begin{array}{l}\text { Smith } 2008[32] \\
\text { Nair } 2008[31] \\
\text { Filer } 2008[33] \\
\text { Li } 2009[35]\end{array}$ \\
\hline & & rs11209026 & $\begin{array}{l}\text { Early onset of Ps } \\
\text { Ps } \\
\text { PsA }\end{array}$ & $\begin{array}{l}\text { Smith } 2008 \text { [32] } \\
\text { Nair } 2008 \text { [31]; } \\
\text { Filer } 2008 \text { [33] }\end{array}$ \\
\hline & & rs2201841 & $\begin{array}{l}\text { Ps } \\
\text { RA }\end{array}$ & $\begin{array}{l}\text { Indhumanthi } 2016 \text { [16] } \\
\text { Farago 2008 [40] }\end{array}$ \\
\hline \multirow[t]{2}{*}{$I L-1 B$} & \multirow{2}{*}{$\begin{array}{l}\text { Mediator of the inflammatory response, } \\
\text { inhibits Treg cells, necessary for } \\
\text { differentiation of Th17 }\end{array}$} & rs16944 & $\begin{array}{l}\text { Ps, PsA } \\
\text { RA }\end{array}$ & $\begin{array}{c}\text { Reich } 2002[41] \\
\text { Tolusso } 2006[42]\end{array}$ \\
\hline & & rs1143634 & $\begin{array}{l}\text { Ps, PsA } \\
\text { RA }\end{array}$ & $\begin{array}{c}\text { Reich } 2002[41] \\
\text { Tolusso } 2006 \text { [42] } \\
\end{array}$ \\
\hline \multirow[t]{3}{*}{ IL-10 } & \multirow[t]{3}{*}{$\begin{array}{l}\text { Inhibits Th1 differentiation, promoting Treg } \\
\text { differentiation }\end{array}$} & rs1800896 & $\begin{array}{c}\text { Ps } \\
\text { RA } \\
\text { Response to anti-TNF in RA }\end{array}$ & $\begin{array}{l}\text { Baran } 2008 \text { [43] } \\
\text { Lee } 2012 \text { [44] } \\
\text { Liu } 2008 \text { [45] }\end{array}$ \\
\hline & & rs1800871 & Ps & Baran 2008 [43] \\
\hline & & rs1800872 & $\begin{array}{l}\text { Ps } \\
\text { RA }\end{array}$ & $\begin{array}{l}\text { Baran } 2008[43] \\
\text { Lee } 2012[44]\end{array}$ \\
\hline
\end{tabular}


Table 1. Cont.

\begin{tabular}{|c|c|c|c|c|}
\hline Gene & Gene function & Genetic variant & Associations & References \\
\hline $\mid L-21$ & $\begin{array}{l}\text { Increased hyperproliferation of psoriatic } \\
\text { skin, increased mononuclear inflammation }\end{array}$ & rs6822844 & $\begin{array}{c}\text { RA } \\
\text { Ps, PsA }\end{array}$ & $\begin{array}{l}\text { Zhernakova } 2007 \text { [46] } \\
\text { Schrodi } 2008 \text { [47] }\end{array}$ \\
\hline \multirow[t]{3}{*}{$T N F$} & \multirow[t]{3}{*}{$\begin{array}{l}\text { Mediates numerous inflammatory and } \\
\text { immunoregulatory activities }\end{array}$} & $\begin{array}{l}r s 1800629 \\
(-308 G>A)\end{array}$ & $\begin{array}{c}\text { Genotype AA - poor response to } \\
\text { etanercept in RA } \\
\text { Genotype AG - a reduced risk } \\
\text { of Ps }\end{array}$ & Maxwell 2008 [28] \\
\hline & & $\begin{array}{l}\mathrm{rs} 361525 \\
(-238 \mathrm{G}>\mathrm{A})\end{array}$ & $\begin{array}{c}\text { Genotype GA - poor response to } \\
\text { infliximab in RA and an increased } \\
\text { risk of Ps }\end{array}$ & $\begin{array}{l}\text { Maxwell } 2008 \text { [28] } \\
\text { Li } 2007 \text { [17] }\end{array}$ \\
\hline & & rs1799724 & $\begin{array}{l}\text { Positive response to etanercept, } \\
\text { poor response to infliximab and } \\
\text { adalimumab in Ps }\end{array}$ & Vasilopoulos 2012 [25] \\
\hline$H L A-C$ & $\begin{array}{l}\text { Belongs to the MHC class I receptors, } \\
\text { expressed in nearly all cells, and present } \\
\text { small peptides to the immune system, } \\
H L A-C \text { is a locus on chromosome } 6 \text {, which } \\
\text { encodes for a large number of } H L A-C \text { alleles } \\
\text { that are class-I MHC receptors }\end{array}$ & rs10484554 & $\begin{array}{c}\text { Positive response to adalimumab } \\
\text { in Ps, poor response to } \\
\text { ustekinumab in Ps }\end{array}$ & Masouri 2016 [29] \\
\hline IL-17R & $\begin{array}{l}\text { IL-17 receptor binds interleukin } 17 \mathrm{~A} \text {, } \\
\text { protects against extracellular pathogens, } \\
\text { but conversely promotes inflammatory } \\
\text { pathology in autoimmune diseases }\end{array}$ & rs4819554 & Positive response to anti-TNF in Ps & Batalla 2018 [24] \\
\hline \multirow[t]{2}{*}{ ERAP1 } & \multirow{2}{*}{$\begin{array}{l}\text { Endoplasmic reticulum aminopeptidase } 1 \text {, } \\
\text { encoded protein is an aminopeptidase } \\
\text { involved in trimming HLA class I-binding } \\
\text { precursors so that they can be presented } \\
\text { on MHC class I molecules }\end{array}$} & rs151823 & $\begin{array}{c}\text { Positive response to ustekinumab } \\
\text { in Ps }\end{array}$ & Masouri 2016 [29] \\
\hline & & rs26653 & $\begin{array}{l}\text { Positive response to ustekinumab } \\
\text { in Ps }\end{array}$ & Masouri $2016[29]$ \\
\hline
\end{tabular}

morphisms influenced the treatment with infliximab or adalimumab [25]. Some polymorphisms in the TNFAIP3 gene have been associated with Ps, RA, type 1 diabetes mellitus, systemic lupus erythematosus (SLE), and celiac disease. Tejasvi et al. have reported the impact of two TNFAIP3 gene polymorphisms (rs2230926 in exon 7 and rs610604 in intron 3) on positive response to anti-TNF $\alpha$ treatment of Ps [26].

Recently, the influence of the PDE3A-SLCO1C1 (phosphodiesterase $3 \mathrm{~A}$ - solute carrier organic anion transporter family member 1C1) locus on the response to anti-TNF agents has been demonstrated in Ps. Interestingly, the allele G of rs3794271 in the SLCO1C1 gene was previously associated with the lack of response in RA [27]. A number of relatively small studies have also investigated TNF genetic variants as a response marker in the context of anti-TNF therapy in RA. Analyses of the TNF gene variant in the position -308 (rs1800629) in RA revealed that genotype AA was associated with a significantly poorer response compared with genotype GG in patients receiving etanercept, but not infliximab. In turn, in locus -238 (rs361525) of the TNF gene, the genotype GA was correlated with a poorer response to infliximab, but not etanercept in RA [28].
In the study in a Greek cohort of Ps patients, rs10484554 in the HLA-C gene showed a positive correlation with a response to anti-TNF agents (especially to adalimumab) but not to ustekinumab, while rs151823 and rs26653 in the ERAP1 gene showed associations with an improved response to anti-IL12/23 therapy [29]. Talamonti et al. observed an increased and quicker reaction to ustekinumab in HLA-Cw6 positive Ps patients, whereas analysis of TNFAIP3 rs610604 polymorphism did not show any significant association with response to ustekinumab [30]. Associations between gene variants and Ps, other autoimmune diseases as well as response to treatment that have already been discovered, are presented in Table 1 [31-47].

Although the biological drugs have greatly improved the treatment of Ps, PSA, RA and CD, some percentage of patients fail to respond to the treatment or develop severe adverse drug reactions. Moreover, these medicines are very expensive and do not cure the disease. Characterization of the pharmacogenetic profile associated with response to a specific drug enables to choose the right treatment for the right person without the risk of adverse reactions, increase the efficacy of therapy and reduce costs. 


\section{Conclusions}

The reliable knowledge of the influence of some gene polymorphisms (e.g. IL-12B, IL-13, IL-23R, IL-1B, IL-10, IL-21, $T N F-\alpha$ ) on the Ps risk is necessary to identify individuals at high risk of developing Ps or PSA. There are only few studies identifying SNPS (e.g. TNFR1B, TNFAIP3, HLA-C, $I L-17 R, E R A P 1$ ) related with response to biologic treatment in Ps or PSA (mainly anti-TNF treatment). Large prospective studies are necessary to validate genetic markers associated with various types of therapy used in Ps and PsA before implementation in the daily clinical practice.

That is why this subject might be of interest for further collaborative studies.

\section{Conflict of interest}

The authors declare no conflict of interest.

\section{References}

1. Bieber T, Nestle F (eds.). Personalized Treatment Options in Dermatology. Springer-Verlag, Berlin Heidelberg 2015; 86-7.

2. International Human Genome Sequencing Consortium. Finishing the euchromatic sequence of the human genome. Nature 2004; 431: 931-45.

3. International HapMap Consortium. A second generation human haplotype map of over 3.1 million SNPs. Nature 2007; 449: 851-61.

4. Margulies M, Egholm M, Altman WE, et al. Genome sequencing in microfabricated high-density picolitre reactors. Nature 2005; 437: 376-80.

5. Choi M, Scholl UI, Ji W, et al. Genetic diagnosis by whole exome capture and massively parallel DNA sequencing. Proc Natl Acad Sci USA 2009; 106: 19096-101.

6. Zheng G, Tsai H, Tseng LH, et al. Test feasibility of next-generation sequencing assays in clinical mutation detection of small biopsy and fine needle aspiration specimens. Am J Clin Pathol 2016; 145: 696-702.

7. Villaseńor-Park J, Ortega-Loayza AG. Microarray technique, analysis, and applications in dermatology. I Invest Dermato 2013; 133: e7.

8. DeCoster E, Alves de Medeiros A, Bostoen J, et al. A multileveled approach in psoriasis assessment and follow-up: a proposal for a tailored guide for the dermatological practice. J Dermatolog Treat 2016; 27: 298-310.

9. Brandrup F, Hauge M, Henningen K, et al. Psoriasis in an unselected series of twins. Arch Dermatol 1978; 114: 874-8.

10. Marrakchi S, Guigue P, Renshaw BR, et al. Interleukin -36-receptor antagonist deficiency and generalized pustular psoriasis. N Engl J Med 2011; 365: 620-8.

11. Sun LD, Cheng H, Wang ZX, et al. Association analyses identify six new psoriasis susceptibility loci in the Chinese population. Nat Genet 2010; 42: 1005-9.

12. Nair RP, Stuart P, Henseler T, et al. Localization of psoriasissusceptibility locus PSORS1 to a 60-kb interval telomeric to HLA-C. Am J Hum Genet 2000; 66: 1833-44.

13. Strange A, Capon F, Spencer CC, et al. A genome-wide association study identifies new psoriasis susceptibility loci and an interaction between HLA-C and ERAP1. Nat Genet 2010; 42: 1000-4.

14. Capon F, Di Meglio P, Szaub J, et al. Sequence variants in the genes for interleukin-23 receptor (IL23R) and its ligand
(IL12B) confer protection against psoriasis. Hum Genet 2007; 122: 201-6.

15. Cargil M, Schrodi SJ, Chang M, et al. A large-scale genetic association study confirms IL12B and leads to the identification of IL23R as psoriatic - risk genes. Am J Hum Genet 2007; 80: 273-90.

16. Indhumanthi S, Rajappa M, Chandrashekar L, et al. Investigation of association of the IL-12B and IL-23R genetic variations with psoriatic risk in a South Indian Tamil cohort. Hum Immonol 2016; 77: 54-62.

17. Li C, Wang G, Gao Y, et al. TNF-alpha gene promoter-238G >A and $-308 \mathrm{G}>\mathrm{A}$ polymorphisms alter risk of psoriasis vulgaris: a meta-analysis. J Invest Dermatol 2007; 127: 1886-92.

18. Bowcock AM, Cookson WO. The genetics of psoriasis, psoriatic arthritis and atopic dermatitis. Hum Mol Genet 2004; 13: R43-55.

19. Menter A, Papp KA, Gooderham M, et al. Drug survival of biologic therapy in a large, disease-based registry of patients with psoriasis: results from the Psoriasis Longitudinal Assessment and Registry (PSOLAR). J Eur Acad Dermatol Venereol 2016; 30: 1148-58.

20. Henseler T, Christophers E. Psoriasis of early and late onset: characterization of two types of psoriasis vulgaris. J Am Acad Dermatol 1985; 13: 450-6.

21. Biomarkers Definition Working Group. Biomarkers and surrogate endpoints: preferred definitions and conceptual framework. Clin Pharmacol Ther 2001; 69: 89-95.

22. Ho PY, Barton A, Worthington J, et al. Investigating the role of the HLA-CW*06 and HLA-DRB1 genes in susceptibility to psoriasis arthritis: comparison with psoriasis and undifferentiated inflammatory arthritis. Am Rheum Dis 2008; 67: 677-82.

23. Pérez-Prieto R, Cabaleiro T, Dauden E, et al. Gene polymorphisms that can predict response to anti-TNF therapy in patients with psoriasis and related autoimmune diseases. Pharmacogenomics J 2013; 13: 297-305.

24. Batalla A, Coto E, Gomez J, et al. IL-17RA gene variants and anti-TNF response among psoriasis patients. Pharmacogenom J 2018; 18: 76-80.

25. Vasilopoulos Y, Manolika M. Pharmacogenetic analysis of TNF, TNFRSF1A, and TNFRSF1B gene polymorphisms and prediction of response to anti-TNF therapy in psoriasis patients in Greek population. Mol Diagn Ther 2012; 16: 29-34.

26. Tejasvi T. TNFAIP3 gene polymorphisms are associated with response to TNF blockade in psoriasis. I Invest Dermatol 2012; 132: 596-600.

27. Julià A, Ferrándiz C, Dauden E, et al. Association of the PDE3A-SLCO1C1 locus with the response to anti-TNF agents in psoriasis. Pharmacogenom J 2015; 15: 322-5.

28. Maxwell JR, Potter C, Hyrich KL, et al. Association of the tumour necrosis factpr-308 variant with differential response to anti-TNF agents in the treatment of rheumatoid arthritis. Hum Mol Genet 2008; 17: 3532-8.

29. Masouri S, Stefanaki I, Ntritsos G, et al. A pharmacogenetic study of psoriasis risk variants in a Greek population and prediction of responses to anti-TNF-alpha and anti-IL-12/23 agents. Mol Diagn Ther 2016; 20: 221-5.

30. Talamonti M, Botti E, Galluzzo M, et al. Pharmacogenetics of psoriasis: HLA-Cw6 but not LCE3B/3C deletion nor TNFAIP3 polymorphism predisposes to clinical response to interleukin 12/23 blocker ustekinumab. Br J Dermatol 2013; 169: 458-63.

31. Nair RP, Ruether A, Stuart PE, et al. Polymorphisms of the IL12B and IL23R genes are associated with psoriasis. J Invest Dermatol 2008; 128: 1653-61. 
32. Smith RL, Warren RB, Eyre S, et al. Polymorphisms in the IL-12beta and IL-23 R genes are associated with psoriasis of early onset in UK cohort. J Invest Dermatol 2008; 128: 1325-7.

33. Filer C, Ho P, Smith RL, et al. Investigation of association of the IL12B and IL23R genes with psoriatic arthritis. Arthritis Rheum 2008; 58: 3705-9.

34. Liu Y, Helms C, Liao W, et al. A genome-wide association study of psoriasis and psoriatic arthritis identifies new disease loci. PLoS Genet 2008; 4: e100004.

35. Li Y, Begovich AB. Unraveling the genetics of complex diseases: susceptibility genes for rheumatoid arthritis and psoriasis. Semin Immunol 2009; 21: 318-27.

36. Chang M, Li Y, Yan C, et al. Variants in the $5 q 31$ cytokine gene cluster are associated with psoriasis. Genes Immun 2008; 9: 176-81.

37. Duffin KC, Freeny IC, Schrodi SJ. Association between IL13 polymorphisms and psoriatic arthritis is modified by smoking. J Invest Dermatol 2009: 129: 2777-83.

38. Eder L, Chandran V, Pellett F, et al. IL13 gene polymorphism is a marker for psoriatic arthritis among psoriasis patients. Ann Rheum Dis 2011; 70: 1594-8.

39. Bowes J, Eyres S, Flynn E, et al. Evidence to support IL-13 as a risk locus for psoriatic arthritis but not psoriasis vulgaris. Ann Rheum Diss 2011; 70: 1016-9.

40. Farago B, Magyari L, Safrany E, et al. Functional variants of interleukin-23 receptor gene confer risk for rheumatoid arthritis but not for systemic sclerosis. Ann Rheum Dis 2008; 67: 248-50.

41. Reich K, Mossner R, Konig IR, et al. Promoter polymorphisms of the genes tumor necrosis factor-alpha and interleukinlbeta are associated with different suntypes of psoriasis characterized by early and late disease onset. J Invest Dermatol 2002; 118: 155-63.

42. Tolusso B, Pietrapertosa D, Morelli A, et al. IL-1B and IL-1RN gene polymorphisms in rheumatoid arthritis: relationship with protein plasma levels and response to therapy. Pharmacogenomics 2006; 7: 683-695.

43. Baran W, Szepietowski JC, Mazur G, et al. IL-6 and IL-10 promoter gene polymorphisms in psoriasis vulgaris. Acta Derm Venereol 2008; 88: 113-6.

44. Lee YH, Bae SC, Choi SJ, et al. Associations between interleukin-10 polymorphisms and susceptibility to rheumatoid arthritis: a meta-analysis. Mol Biol Rep 2012; 39: 81-7.

45. Liu C, Batliwalla F, Li W, et al. Genome-wide association scan identifies candidate polymorphisms associated with differentia response to anti-TNF treatment in rheumatoid arthritis. Mol Med 2008; 14: 575-81.

46. Zhernakova A, Alizadeh BZ, Bevova M, et al. Novel association in chromosome $4 q 27$ region with rheumatoid arthritis and confirmation of type 1 diabetes point to a general risk locus for autoimmune diseases. Am J Hum Genet 2007; 81: 1284-8.

47. Schrodi SJ. Genome-wide association scan in psoriasis: new insights into chronic inflammatory disease. Expert Rev Clin Immunol 2008; 4: 565-71. 